\title{
"It May Be Truth, But It Is Not Evidence": Paul du Chaillu and the Legitimation of Evidence in the Field Sciences
}

\author{
Stuart McCook
}

$I^{\mathrm{N}}$

N THE SPRING OF 1861, gorillas had captivated the public imagination in England. The recent publication of Darwin's On the Origin of Species had fueled the ongoing debate about the place of humans in nature. A key piece of evidence in the debate was the recently discovered gorilla. In the pages of learned journals and in the more popular Athenaeum, Richard Owen and Thomas Henry Huxley debated the significance of gorilla skeletons recently brought to England. They based their arguments about the uniqueness of man on the physiology of the gorilla, which was anatomically closer to man than was any other animal. Owen argued that the human brain had a lobe, the hippocampus minor, that distinguished it from all other living organisms. Huxley countered by arguing that the hippocampus minor was not peculiar to the human brain. The gorilla skulls over which Huxley and Owen debated had been brought to England with great fanfare by a little-known explorer named Paul du Chaillu (see Fig. 1).'

From 1856 to 1859 , Du Chaillu had traveled through western equatorial Africa, studying the lands and people and collecting flora and fauna. He brought a choice selection of his collections to England early in 1861, where he was quickly made a celebrity. He described his adventures to packed halls at the Royal Geographical Society and at the Royal Institution in London, with a row of stuffed gorillas on the stage and gorilla skulls on hand beside the lectern. ${ }^{2}$ The evening after du Chaillu

\footnotetext{
* Department of History, 129 Dickinson Hall, Princeton, NJ 08544.

This article is based on my master's thesis, "The Monkey Business: Paul Du Chaillu and Nonscientist Roles Within the Scientific Community" (Rensselaer Polytechnic Institute, 1990). Prof. Sydney Ross generously provided me with the manuscript that introduced me to the world of Paul du Chaillu. I would also like to thank P. Thomas Carroll, Deborah J. Coon, Gerald L. Geison, Robert E. Kohler, Henrika Kuklick, Sal Restivo, two anonymous reviewers, and my classmates at Rensselaer Polytechnic Institute and Princeton University for their comments and guidance.

1 For two perspectives of the scientific world of Victorian London, see Adrian Desmond, Archetypes and Ancestors: Paleontology in Victorian London, 1850-1875 (Chicago: University of Chicago Press, 1982), particularly pp. 74-76; and Nicholaas Rupke, Richard Owen: Victorian Naturalist (New Haven: Yale University Press, 1994). Owen and Huxley refer to du Chaillu's gorilla skeletons in, among other places, "The Gorilla and the Negro," Athenaeum, 23 March 1861, no. 1743:395-396; and T. H. Huxley, "Man and the Apes," Athenaeum 13 April 1861, no. 1746:498. p. 276.

Lynn Barber, The Heyday of Natural History, 1820-1870 (New York: Doubleday \& Co., 1980),
} (C) 1996 by The History of Science Society. All rights reserved. 0021-1753/96/8401-0001\$01.00 


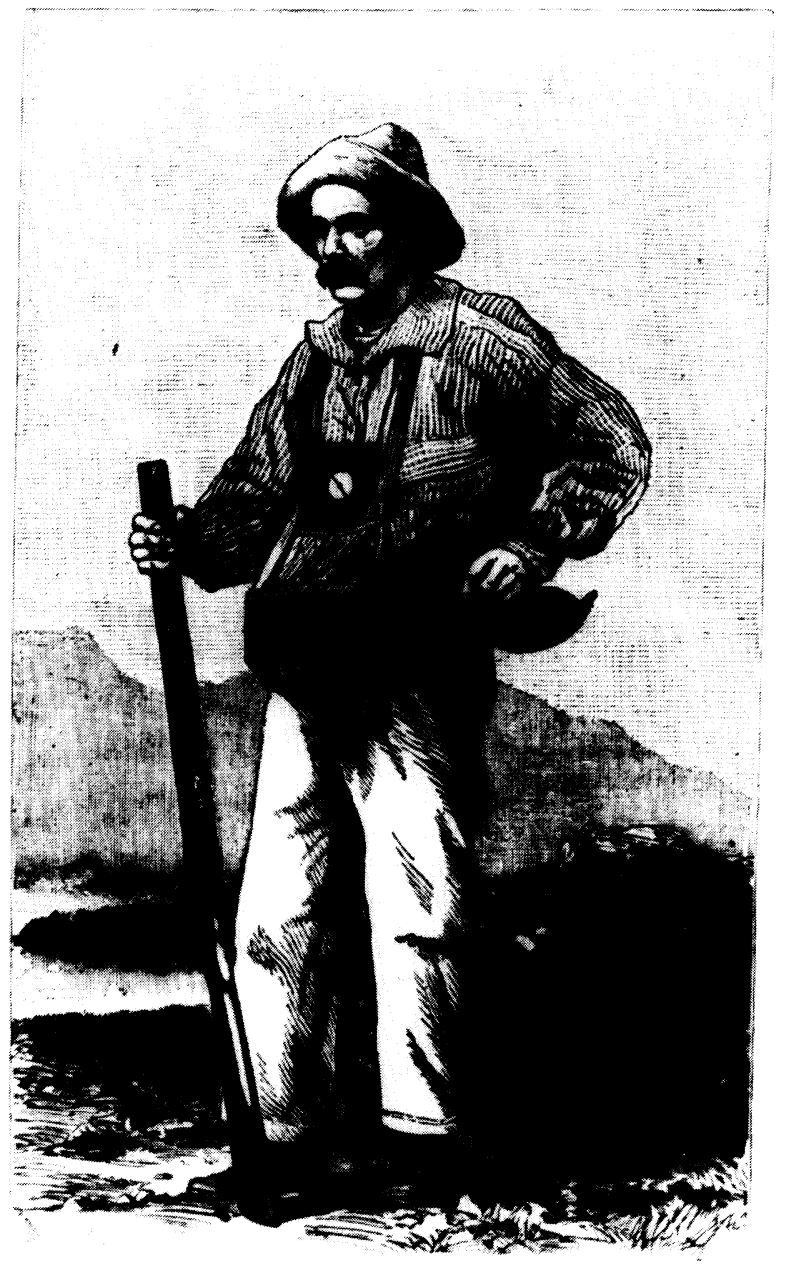

Figure 1. "Paul du Chaillu in his african costume," from Stories of the Gorilla Country (New York: Harper and Brothers, 1897), xii.

lectured at the Royal Institution, Owen presented a paper there on the distinction between the Negro and the gorilla, based on skulls given to him by du Chaillu.

Du Chaillu's honeymoon with the British natural history community was shortlived. Explorations and Adventures in Equatorial Africa, du Chaillu's narrative of his travels in Africa, was published in May 1861. Inconsistencies and ambiguities in the book provoked a politely fierce debate that temporarily eclipsed the debate over humanity's place in nature. The argument over du Chaillu's reliability was one of the few instances when scientists in Victorian England publicly discussed issues of what constituted good scientific practice and who made a good scientist, rather than what constituted good scientific theory.

Although Paul du Chaillu is deservedly not considered one of the great figures in Victorian science, his case brings to light some issues of interest to historians of science. In recent years historians of science have begun to look at people who were essential to the production of scientific knowledge, but who remained hidden from 
public view. Steven Shapin has written about the "invisible technicians" who worked on Robert Boyle's experiments. ${ }^{3}$ The Victorian era had its own share of invisible technicians, most of whom normally remained out of the public eye. Invisibility was somewhat harder to establish in the field sciences, however, since the field collectors could not easily be written out of the story of how natural history specimens were obtained. Still, the scientific communities in England and the United States developed strategies of accommodating field collectors that ensured that they remained relatively invisible. The controversy over du Chaillu threw a spotlight onto a process that normally remained behind the scenes.

Historians of science have also recently begun to look at the production of knowledge in the field sciences and to explore how it differs from knowledge production in the laboratory. The controversy over du Chaillu illustrates the fragility of the process of legitimation of scientific knowledge in natural history during the Victorian era. Field observations in natural history depended very heavily on the perceived credibility of the person who made them. Observations without clear provenance had greatly diminished value. As with art objects, the provenance of natural history objects depended partly on concrete records and partly on the credibility of the person who offered it. Credibility was, in turn, strongly tied to the social standing of the observer. Du Chaillu's class, educational background, and race quickly became key issues in the debate over the scientific worth of the Explorations. The strategies that du Chaillu's detractors used to tear him down and those that his supporters used to defend him give a detailed picture of the process by which objects collected in the field became scientific evidence.

\section{THE MAKING OF A FIELD EXPERT, 1831-1861}

Paul du Chaillu's voyage to equatorial Africa took place during the heyday of scientific exploration, which began with the voyages of Cook in the late eighteenth century. Scientists, bureaucrats, and businessmen at the European and American centers of power sought information about the unknown regions of Asia, Africa, and America. This knowledge was part of the establishment of European political, economic, and intellectual hegemony over the region. ${ }^{4}$ Metropolitan governments, museums, botanical gardens, zoos, and scientific societies eagerly sought natural history objects and observations from travelers to these unknown regions.

Du Chaillu was probably born around 1831. His father, Charles-Alexis Duchaillu, was a French trader who had worked on the Île Bourbon (Réunion) before moving to the Gabon in the mid-1840s. ${ }^{5}$ Little is known about his mother, who certain

\footnotetext{
${ }^{3}$ Steven Shapin, “The Invisible Technician," American Scientist, 1989, 77:554-563.

${ }^{4}$ See Michael Adas, Machines as the Measure of Men: Science, Technology, and Ideologies of Western Dominance (Ithaca, N.Y.: Cornell Univ. Press, 1989), 133-165; William H. Goetzmann, New Lands, New Men: America and the Second Great Age of Discovery (New York: Penguin, 1987).

${ }^{5}$ The best historical reconstruction and analysis of du Chaillu's life appears in H. H. Bucher's "Canonization by Repetition: Paul du Chaillu in Historiography," Revue Française d'Histoire d'Outre-Mer, 1979, 66:15-32. Through painstaking research, Bucher reconstructs du Chaillu's early years, which du Chaillu deliberately obscured. Michel Vaucaire's Paul du Chaillu: Gorilla Hunter. Being the Life and Extraordinary Adventures of Paul du Chaillu (New York: Harper \& Bros., 1930) is an uncritically celebratory biography of du Chaillu. Unfortunately, it is vague about du Chaillu's life before he came to America. Other reliable biographical fragments are Helen Everston Smith,
} 
historians and contemporaries of du Chaillu have suspected was black or of mixed race. Others, however, conclude that she was Italian, apparently because of the Italian ring of "Belloni," du Chaillu's middle name. Du Chaillu apparently spent some of his teenage years in Paris and was almost certainly there during the February Revolution of 1848. The seventeen-year-old Paul first arrived in the Gabon late in 1848, where he enrolled at the American Protestant mission school. ${ }^{6}$ During du Chaillu's formative years, both Europeans and Americans had extensive commercial interests in Africa. By the mid-1850s a well-established trading network had been formed between Europeans and Africans along the African coast, reaching far inland. In the late 1840 s and early 1850 s du Chaillu made several trips to the interior on behalf of his father's company. On these voyages, he learned about the culture, flora, and fauna of equatorial Africa.

Du Chaillu had become fascinated with the United States during his time at the American mission school. In 1852 the chief missionary, John Wilson, arranged for du Chaillu to teach French at a girl's school in Carmel, New York. When he arrived in the United States, he found that his background gave him an expertise valued by American scientists. Western commercial, political, and religious involvement in Africa had spawned a great deal of popular curiosity about Africa. Travel narratives such as those of Stanley, Humboldt, and Burton were devoured by a public eager to find out about an exotic world. As a European who had lived in Africa for many years, du Chaillu became a popular dinner guest and speaker. He wrote articles on Africa for the New York Tribune and lectured at learned societies. His articles attracted the attention of some members of the Academy of Natural Sciences of Philadelphia, to whom he donated a collection of natural history specimens that he had brought with him from Africa. ${ }^{7}$ Duly impressed, several members of the Academy of Natural Sciences of Philadelphia raised money for du Chaillu to make a collecting expedition to Africa. Natural history specimens from Africa had been of great interest in the United States. Ten years earlier, a missionary named Savage had published the first description of the gorilla in the Journal of the Boston Society of Natural History, gaining worldwide attention for the society. Du Chaillu's sponsors in Philadelphia hoped for a similar coup.

Du Chaillu returned to the Gabon, on the west coast of Africa, in October 1855. His purpose was "to spend some years in the exploration of a region of territory lying between lat. $2^{\circ}$ north and $2^{\circ}$ south, and stretching back from the coast to the mountain range called the Sierra del Crystal, and beyond as far as I should be able to penetrate." ${ }^{8}$ He returned to the United States in 1859, having spent several years exploring the region and mapping the outlets of the Ogobay, Fernand Vaz, and Mexias rivers. He had also collected plants and animals, sending periodic shipments and descriptions to his sponsors in Philadelphia. Many of these were duly described in the Proceedings of the Academy. John Cassin, vice president of the Academy, de-

\footnotetext{
"Reminiscences of Paul Belloni du Chaillu," The Independent, 1903, 55:1,146-1,148; and Edward Clodd, Memories (New York: G. P. Putnam's Sons, 1916), pp. 71-75. The entries in the Dictionary of American Biography and Who Was Who in American History-Science and Technology are unreliable.

${ }^{6}$ Bucher, "Canonization," pp. 16-18; Smith, "Reminiscences," p. 1,147.

${ }^{7}$ Bucher, "Canonization," p. 18.

${ }^{8}$ Paul Du Chaillu, Explorations and Adventures in Equatorial Africa (New York: Harper \& Brothers, 1861$)$, p. 25 .
} 
scribed over three hundred bird specimens, all of which had been sent to him by du Chaillu. ${ }^{9}$ By du Chaillu's own account, he had travelled some 8,000 miles on foot, "unaccompanied by any other white men." He claimed to have found sixty new species of birds and twenty new species of quadrupeds, as part of the total of three thousand animals and birds he collected on the voyage. ${ }^{10}$ Although the details of these claims were later questioned, it was clear that he had gone to Africa and made substantial collections.

Upon du Chaillu's return late in 1859, his relations with the Academy of Natural Sciences of Philadelphia began to sour. Du Chaillu had apparently been under the impression that the Academy itself, rather than individual members, had formally sponsored his voyage. " When he presented the bill for his work and for the specimens sent to the Academy and displayed in its hall, however, the Academy denied any obligation to pay him. The secretary of the Academy regretted "that $\mathrm{Mr}$. Du Chaillu should have erroneously supposed that he was making explorations and collections in western Africa under the patronage and at the cost of the Acad[em]y, when in fact he had merely the favor of many of its members as joint purchasers of parts of his collections." The cash-strapped Academy could simply have been trying to get out of having to pay his substantial bill of $\$ 866.50$. "The Academy of Philadelphia owes me money still," wrote an aggrieved du Chaillu over a year after his return, "the amount I paid to the vessels which took me home is more than the whole amount of money I have received or will ever receive for the objects they have bought." ${ }^{22}$ His negotiations with the Academy lasted well over a year before he finally gave up in frustration.

Du Chaillu spent much of 1860 touring the United States with his collections of exotic stuffed animals, giving popular lectures. He also began work on the narrative of his voyage to Africa, which was to be published by Harper's publishing company. Du Chaillu continued his negotiations with Richard Owen, the superintendent of the British Museum of Natural History, for the sale of parts of his collection, especially

\footnotetext{
${ }^{9}$ John Cassin, "Description of New Species of Birds from Western Africa, in the collection of the Academy of Natural Sciences of Philadelphia," Proceedings of the Academy of Natural Sciences of Philadelphia, April 1855, 7:324-328; "Descriptions of new species of African Birds, in the Museum of the Academy of Natural Sciences of Philadelphia, collected by Mr. P. B. du Chaillu, in Equatorial Africa," Proc. Acad. Nat. Sci. Phil., August 1856, 8:156-159; "Catalogue of Birds Collected at Cape Lopez, Western Africa, by Mr. P. B. du Chaillu, in 1856, with notes and descriptions of new species," Proc. Acad. Nat. Sci. Phil., December 1856, 8:316-322; "Catalogue of Birds collected on the Rivers Camma and Ogobai, Western Africa, by Mr. P. B. du Chaillu, with notes and descriptions of new species," Proc. Acad. Nat. Sci. Phil., January 1859, 11:30-55; April 1859, 11:133-144; June 1859, $11: 172-176$.

${ }^{10}$ Du Chaillu, Explorations, p. x.

${ }^{11}$ Members of the Academy also gave that impression, although the wording was ambiguous. An account written in 1857, while du Chaillu was still collecting in Africa, describes his original arrangement with the Academy as follows: "At a meeting of the Academy of Natural Sciences of Philadelphia, held October 16, 1855 [,] 'Mr. Cassin announced that M. du Chaillu was about to return to Western Africa, for the purpose, exclusively, of geographical exploration, and the collection of objects of Natural History. Arrangements have been made to secure, for the cabinet of this Society, the collections of Birds especially, and also of some other objects.' "In Alfred Maury, Indigenous Races of the Earth (Philadelphia: J. B. Lippincott \& Co., 1857), p. 324, fn. 243. See also Bucher, "Canonization," p. 23.

${ }^{12}$ The secretary of the Academy to Paul du Chaillu, 5 March 1860, MSS Coll. \#464, Library of the Academy of Natural Sciences of Philadelphia; Paul du Chaillu to W. J. Vaux, 31 January 1860. MSS Coll. \#567, Library of the Academy of Natural Sciences of Philadelphia; Paul du Chaillu to Richard Owen, 1861. MSS 323A, Smithsonian Institution Libraries.
} 
the gorillas. Du Chaillu had first made the offer to Owen in 1859, while he was still in Africa. Jeffries Wyman, the prominent Harvard anatomist who had coauthored the first scientific paper on the gorilla, reviewed du Chaillu's collections while du Chaillu was lecturing in Boston. Du Chaillu presented a paper on the gorilla to the Boston Society of Natural History, of which Wyman was president. The Society elected du Chaillu a corresponding member of the Society. Although he remained a corresponding member until his death in 1903, he never presented another paper there. Du Chaillu's participation in the Society was largely symbolic. ${ }^{13}$

Prior to 1861 , du Chaillu would have been considered the ideal field collector. $\mathrm{He}$ had specialized knowledge about Africa that was not widely shared. He avidly collected objects of natural history that were greatly valued by metropolitan scientific communities. Tensions with the Academy of Natural Sciences of Philadelphia notwithstanding, du Chaillu enjoyed good relations with prominent scientists and scientific societies on both sides of the Atlantic. He encouraged scientists to study and describe his collections and offered to sell them some of the most scientifically significant objects. In his public lectures he emphasized the more dramatic aspects of his travels - encounters with cannibal tribes and savage animals-leaving the scientific analysis of his discoveries to the natural history community. When he attempted to do a scientific analysis of his own, however, his comfortable relationship with the natural history communities quickly fell apart.

\section{KNOWLEDGE CLAIMS AND SOCIAL STANDING IN THE FIELD SCIENCES}

In the nineteenth century the only people who had the authority to produce scientific knowledge were the self-selecting "gentlemen of science." ${ }^{14}$ The gentlemanly specialists who studied geology or natural history were caught between the traditional disdain for manual labor on the one hand and the Baconian ideal of empirical research on the other. Geologists, for example, saw fieldwork as a rite of initiation and passage into the community. Like geology, most of natural history was necessarily tied to specific places. One had to travel to obtain samples. But scientists in Victorian England and the United States had strong ties to their metropolitan communities and so were often unable or unwilling to be away from the metropolis for the long periods that collecting expeditions required. John Cassin, an ornithologist and vice president of the Academy of Natural Sciences of Philadelphia, cautioned that

\footnotetext{
${ }^{13}$ Richard Owen, "On Some Objects of Natural History from the Collection of M. Du Chaillu," Reports of the British Association for the Advancement of Science, 1861:155. In the Jeffries Wyman papers at Harvard Medical School is a series of letters from du Chaillu to Wyman discussing the identification and measurement of du Chaillu's primate skeletons, dated beginning October 1859 and continuing into 1860 . The letters also discuss the sale of the primates to the British museum and du Chaillu's work on the manuscript of his book. A letter from Richard Owen to Wyman dated November 1861 thanks Wyman for his letter of introduction for du Chaillu. Owen had been "well satisfied with [du Chaillu's] conduct of business.” Jeffries Wyman Papers, Countway Library of Medicine, Harvard Medical School. Paul du Chaillu, "Descriptions of the Habits and Distribution of the Gorilla and other Anthropoid Apes," Proceedings of the Boston Society of Natural History, 1860, 7:276-277.

${ }^{14}$ For discussions of the role of social standing in the English scientific community, see Jack Morrell and Arnold Thackray, Gentlemen of Science: Early Years of the British Association for the Advancement of Science (Oxford: Clarendon Press, 1981), Pts. 1 and 3; and Martin Rudwick, The Great Devonian Controversy: The Shaping of Scientific Knowledge Among Gentlemanly Specialists (Chicago: Univ. Chicago Press, 1985), Chs. 2 and 16; for an earlier period, Steven Shapin, "The House of Experiment in Seventeenth-Century England," Isis, September 1988, 79:373-404.
} 
[The delights of the wild] are temporary, and only to be as a teacher,-we must return ever to the social life as the ark of safety, bringing, we may hope, the olive branch of peace with knowledge. For all that I have said, or that anyone else has said, our greatest and truest interests are in society. There only we acquire true cultivation and elevation. Science, Literature, Art, the greatest civilizers, there only flourish. Betake thyself not to the wilderness, or for a period only, and never longer than forty days, - - never! - if there is any help for it. ${ }^{15}$

Gentlemen of science interested in African natural history had to rely on amateur and professional collectors to gather data for them. These collectors were from a diverse range of class backgrounds. A very few were from the same social class as the scientists they served. For example, Henry A. Ward set up a business of collecting and selling natural history specimens in Rochester. ${ }^{16}$ Ward was a professor at the University of Rochester whose primary occupation was the collection and sale of natural history specimens to other naturalists.

The natural history collectors in west Africa were from an unusually wide variety of geographical and social backgrounds. The native Africans who sold gorilla skeletons to whites on the African coast were socially and culturally the furthest removed from the social world of the metropolitan scientific communities. Although the scientists were quite happy to get hold of the skeletons, they only gave credence to native accounts of gorilla behavior if there were no accounts from white witnesses. European travelers, missionaries, traders, and consular officers became a valuable source of natural history objects and observations in the nineteenth century. In 1819, an explorer saw what was later described as a gorilla, although he did not recognize it as such. The American missionary Savage obtained the first gorilla skeletons in the late 1830s from his fellow missionary John Wilson, who was later du Chaillu's teacher in the Gabon. Ship's officers from the French and British naval vessels that patrolled the coast supplemented their incomes by selling exotic plants and animals to museums and collectors in Europe and America. Other gorilla specimens had made it to European museums, but it is not clear how they were obtained. ${ }^{17}$

The transformation of an object collected in the field to an object that appeared in a scientific paper was a long and often tenuous process of intellectual legitimation. Ideally, the collector collected the "natural" object in the field, making careful observations of the circumstances. Then the object and the description of its manner of collection were passed back to the metropolis through as few hands as possible, since each transfer of the object and observations implied a possible degradation of the information. Collectors such as du Chaillu raised problems of authority for the scientists back in the metropolis. The missionaries, ship's officers, and professional collectors were generally not practicing scientists, so their discoveries were treated as tentative knowledge until the collections had been processed and described by a

\footnotetext{
${ }^{15}$ John Cassin, Illustrations of the Birds of California, Texas, Oregon, and British and Russian America (Philadelphia: J. B. Lippincott \& Co., 1856), p. 292.

${ }^{16}$ Sally Gregory Kohlstedt, "Henry A. Ward: The Merchant Naturalist and American Museum Development," Journal of the Society for the Bibliography of Natural History, 1980, 9:647-661.

${ }^{17}$ For a brief overview of the history of the discovery of the gorilla, see Robert Yerkes and Ada Yerkes, The Great Apes: A Study of Anthropoid Life (New Haven: Yale University Press, 1926), Ch. 4, "The Emergence of the Gorilla." See also Isidore Geoffroy Saint-Hilaire, "Description des Mammifères Nouveaux ou Imparfaitement Connus, Famille des Singes," Archives du Museum D'Histoire Naturelle, 1858-1861, 10:1-21.
} 
metropolitan scientist. ${ }^{18}$ Confirmation by a scientist was essential for an object of natural history to become scientific knowledge.

Data from the jungles of Africa, however, was quite valuable to scientists in Europe and America. Describing a significant new plant or animal could greatly improve a scientist's standing within the community. In practice, then, the metropolitan scientists bent the norms for the collection of field data from Africa and other inaccessible regions. Scientists legitimated the findings of the collectors by symbolically incorporating the collectors into the scientific community. The collector would first be made a corresponding member of a scientific society. Then, with the "assistance" of a regular member, the collector presented a paper describing his findings to the society. The collector thereby became a provisional scientist, superficially vested with all the credibility of a professional.

This strategy of making collectors provisional members of scientific societies could yield great benefits. When the missionary Savage obtained the first gorilla skeleton, he was elected a corresponding member of the Boston Society of Natural History. In 1848, he prepared a paper describing his findings with the help of the Harvard anatomist Jeffries Wyman. The paper was duly published in the Society's journal and the Society basked in the glory of a significant new discovery. Savage never published another scientific paper, and seems not to have participated much in any subsequent activities of the Society. ${ }^{19}$ The Academy of Natural Sciences of Philadelphia, the Boston Society of Natural History, and the British societies all treated du Chaillu much the same way a decade later. This pattern was repeated with most other collectors; their participation in the scientific community was symbolic, honorary, and quite limited.

This strategy also carried risks. The process of legitimating knowledge brought from far afield involved many unknowns. Scientific societies took a considerable amount on trust when they elected collectors as members. Both socially and geographically, collectors were often remote from the centers of metropolitan life. Metropolitan scientists often knew little about the social and educational backgrounds and the field practices of the collectors who supplied them. Nor were the collectors subject to the same social and intellectual standards and control that the scientific establishment could impose upon its regular members. ${ }^{20}$ Censure from the scientific community meant little to people who were only marginal members of the community to begin with. Most of the time, neither the collector nor the specimen was subject either to intense scrutiny or controversy, and everything worked out well. On occasion, however, the whole fragile structure of legitimation collapsed, as it did when Richard Owen and Sir Roderick Impey Murchison tried to vest du Chaillu with the authority of a scientist in the British scientific community.

\footnotetext{
${ }^{18}$ Rudwick, The Great Devonian Controversy, pp. 424-425.

${ }^{19}$ How Savage obtained the skeleton is described in "Notice of the External Characters and Habits of the Troglodytes Gorilla, A New Species of Orang from the Gaboon River," Boston Journal of Natural History, 1847, 5:117-119, reprinted in Science in America: Historical Selections, ed. John Burnham (New York: Holt, Reinhart, and Winston, 1971).

${ }^{20} \mathrm{See}$, for example, Brian Wynne, "Between Orthodoxy and Oblivion: The Normalization of Deviance in Science," in On the Margins of Science: The Social Construction of Rejected Knowledge, ed. Roy Wallis. Sociological Review Monograph 27. (Keele, U.K.: University of Keele, 1979), pp. 6784 . Wynne describes how the British physics community of the 1920s, 1930s, and 1940s accommodated the work of the renegade Nobel laureate C. G. Bakala to avoid a controversy that could seriously damage the community.
} 


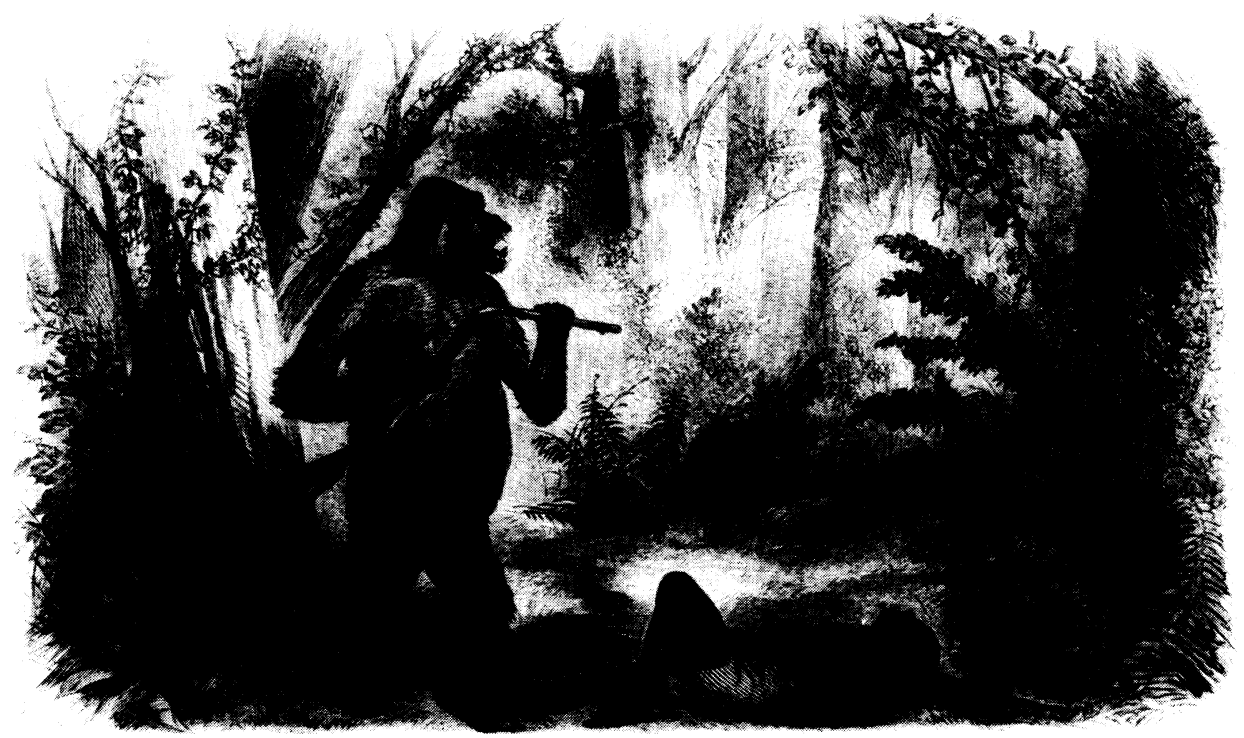

Figure 2. "Death of my hunter," from Explorations and Adventures in Equatorial Africa (New York, Harper and Brothers, 1861), 342. The illustrations in the Explorations reflect the tensions between popular narrative and scientific reporting that also characterize the text. Here, an illustrator at Harper's depicted the death of one of du Chaillu's hunters. Du Chaillu did not see the attack himself, but only described its aftermath.

\section{DU CHAILLU IN ENGLAND: THE BEGINNING OF THE “GORILLA WARS”}

Du Chaillu's Explorations and Adventures in Equatorial Africa enjoyed immediate popular success when it appeared in early May of 1861. It was snapped up by scientists and nonscientists alike. The Explorations was an impressive work over five hundred pages long, but it contained internal tensions. It was supposed to be simultaneously a personal travel narrative and a scientific analysis. The account described new tribes, including the cannibal Fans; new geological features, such as an equatorial mountain range; and new animals, including, as du Chaillu claimed, over "twenty new species of quadrupeds." 21

The structure of the book reflected the difficulty of maintaining a stimulating narrative alongside accurate scientific description. Some passages were written in lurid prose to attract general readers (see Fig. 2). One of the most famous of these passages described du Chaillu's dramatic encounter with a gorilla:

[B]efore us stood an immense male gorilla. ... Nearly six feet high, with immense body, huge chest, and great muscular arms, with fiercely-glaring large deep gray eyes, and a hellish expression of face, which seemed to me like some nightmare vision: thus stood before us the king of the African forests.... His eyes began to flash fiercer fire as we stood motionless on the defensive ... [and] now truly he reminded me of nothing but some hellish dream creature - a being of that hideous order, half man half beast. ...

${ }^{21}$ Du Chaillu, Explorations, p. x. 
Here, as he began another of his roars and beating his breast in rage, we fired, and killed him. ${ }^{22}$

The colorful, dramatic narrative of the book is interrupted two thirds of the way through for a series of analytic chapters on topics such as on the seasons and fevers of Equatorial Africa, tribal politics, the great apes, and the gorilla. These chapters were written in a sober, scientific style in which du Chaillu began behaving as if he were a scientist. For example:

All the features of the gorilla, especially in the male, are exaggerated; the head is longer and narrower; the brain is backward; the cranial crests are of immense size; the jaws are very prominent, and show great power; the canines are very large. The proper cavity of the brain is marked by immense occipital ridges. But the remainder of the skeleton of the gorilla comes much nearer to man than that of any other ape. And, after a careful examination of the osteological facts which have been mentioned; after having observed the live gorilla and studied carefully its mode of progression, I came to the conclusion that the gorilla is the nearest akin to man of all the anthropoid apes. ${ }^{23}$

Du Chaillu's use of the scientific narrative style was an attempt to reinforce the scientific validity of his findings. The vivid narrative resumed clumsily after this dry interlude. ${ }^{24}$

Early reviews of the Explorations criticized du Chaillu's writing style. One of the first published reviews of the book noted that

[f] or a solid book of serious travel, the style is rather airy, and the matter sometimes contradictory, but this latter may arise from the opposite accounts the writer was likely to hear of the same circumstances. To students of Natural History, the volume will, deservedly, be attractive; but we are not disposed to yield full credence to Mr. Du Chaillu's assertion that he is the first white man who has described the gorilla, or the Nestbuilding ape. ${ }^{25}$

This was a polite foreshadowing of the controversy to come.

The most persistent critic of du Chaillu was John Edward Gray. Gray was the keeper of the zoological collection at the British Museum and vice president of the Royal Zoological Society. As keeper, Gray had taken a small collection and built it into one of the finest in Europe. He had published well over a thousand scientific papers in his lifetime. Gray had first examined du Chaillu's specimens at the quarters of the Royal Geographical Society in April. ${ }^{26}$ His criticisms of du Chaillu were perfectly legitimate from a scientific standpoint, but the vigor with which he undertook his task suggested more than simple intellectual dissatisfaction. Richard Owen had been appointed superintendent of the museum some years before, to the displeasure

${ }^{22}$ Ibid., pp. 98-101.

${ }^{23}$ Ibid., p. 417.

${ }^{24}$ The tensions between the narrative and scientific modes of discourse are not unique to du Chaillu's work. Mary Louise Pratt describes the history of the interaction of the two modes in "Fieldwork in Common Places," Writing Culture: The Poetics and Politics of Ethnography, eds. James Clifford and George E. Marcus (Berkeley: Univ. California Press, 1986), especially p. 35.

${ }^{25}$ Unsigned review of Explorations and Adventures in Equatorial Africa, Athenaeum, 11 May 1861, no. 1750: 623 .

${ }_{26}$ The key accounts of du Chaillu's arrival in London are Vaucaire, Gorilla Hunter, pp. 131-137, and John Edward Gray, "Zoological Notes on Perusing M. du Chaillu's 'Adventures in Equatorial Africa,", Annals of Natural History, 1861, 7:463-470; 1861, 8:60-65. 
of Gray and some of the other section heads. They resented Owen's interference in what they considered to be their personal fiefdoms. The problems Gray found with the Explorations gave him the perfect chance to attack Owen vicariously by attacking his protegé du Chaillu. ${ }^{27}$

Gray focused on questioning du Chaillu's competence in the practice of science. In a series of letters to the editor of the Athenaeum spanning several months, Gray attacked the credibility of the book and du Chaillu's authority as a witness. Dissatisfied with the Athenaeum's review of the Explorations, Gray lashed out in a letter to the editor in the following week's issue: "I have examined the collection of mammalia with care," he contended, "and there is not a specimen among them that indicates that the collector had traversed any new region." The gorilla was not new to European science, despite popular assumptions to the contrary: "we have been receiving specimens of them for the last fifteen years . . . until almost every museum in Europe is provided with specimens." The book, he continued, was "full of improbable stories," and some of the illustrations in the book were "copied from figures prepared in this country to represent other kinds, and without acknowledgement." ${ }^{28}$

Gray was unimpressed by Du Chaillu's attempts at naming and identifying new species: "We are overburdened with useless synonyma, and Natural History may be converted into a romance rather than a science by traveller's tales, if they are not exposed at the time." Gray quibbled with almost every new species that du Chaillu had named, saying that most of them had been named elsewhere. There is, in fact, a great deal of ambiguity in identifying new species. "Every man thinks his own geese to be swans," wrote one scientist in the Natural History Review, "and the error of describing old species as new, is one of such ordinary occurrence, that we fear there is scarcely a living Naturalist, who could wash his hands, and say that he was innocent of the offense." ${ }^{29}$ It appears that Gray mostly resented having an amateur name new species, since naming was normally the province of professional scientists.

Gray commented that the popularity of du Chaillu's lectures and the success of the Explorations "become important when the writer is put forward as an authority on subjects upon which I believe he is not qualified to speak; and it is only against the work being considered as what I conceive he himself never intended it to be when it was first compiled (that is, a regular and veracious work of travels and natural history) that I have ever objected or desire to object." In a detailed critique of the zoology of the Explorations, Gray noted that du Chaillu had included reptiles under the mammalia. He also questioned du Chaillu's ability as a collector, specifically his ability to preserve animal skins. Gray described the skins of du Chaillu's gorilla specimens as rotten and fragile because they had been inadequately stuffed. Du Chaillu's method of stuffing the gorilla skins led Gray to conclude that "they could not have been prepared very far inland; for no one would have adopted such an inconvenient and dangerous practice if the skins had to be carried for many miles on the backs of men; and even near the coast it would have been better if the skins

\footnotetext{
27 “Gray, John Edward,” Dictionary of National Biography (hereafter, DNB) 23, pp. 9-10; DNB 42, pp. 435-444; A. E. Gunther, The Founders of Science at the British Museum, 1753-1900 (Suffolk, England: Halesworth Press, 1980), pp. 122-124; Rupke, Richard Owen, p. 319.

${ }^{28}$ John Edward Gray, "The New Traveller's Tales," Athenaeum, 18 May 1861, no. 1751: 662663.

${ }^{29}$ Ibid., p. 662; “The Fauna of Equatorial Africa,” Natural History Review July 1861, 1:290.
} 
had been spread out flat and allowed to dry on both sides, and then had been packed in a small space, as is usual with good collections." ${ }^{30}$

In subsequent letters to the Athenaeum through the summer of 1861, Gray backed up his original charges with even more detailed evidence. Gray showed, for example, that the frontispiece of the Explorations was plagiarized from an article on the gorilla that Isidore Geoffroy Saint Hilaire had published some three years previously in the Archives du Museum. ${ }^{31}$ The version in du Chaillu's book added a strategically placed branch to cover that part of the gorilla's anatomy that would presumably offend Victorian sensibilities. He also showed that many other illustrations in the book were copied from other sources. Gray appears to have been angry at du Chaillu for overstepping his bounds as a collector.

The debate began to center as much on du Chaillu himself as it did on his discoveries. Neither Gray nor the Athenaeum made outright slurs against du Chaillu's character. The editors of the Athenaeum edited one letter that they felt had too much personal invective, and Gray always denied that he was carrying out a personal war ("Gorilla war," Gray punned) against du Chaillu. In fact, he said that "it is no fault of M. Du Chaillu that, to meet a supposed want of one or more of our scientific Societies, he was seized upon and put forth as a scientific traveller and zoologist." Even in private, Gray maintained this charitable tone, while also making more serious accusations about du Chaillu than he dared make in print: "I have always regarded Du Chaillu 'as more sinned against than sinning.' He only wanted strength of mind to tell the truth that the book was not written by him." ${ }^{32}$ Publicly and privately, Gray's tone, while not personally hostile, was still one of paternalistic sympathy. Du Chaillu's credibility among scientists was damaged by repeated accusations that a ghost-writer at Harper's had embellished his accounts to produce a more profitable book.

One way du Chaillu's detractors discounted his claims was to exclude him from the community of scientists. "Traveler's tales" was a term of contempt that cropped up several times during the debate, concerning the works of several people. Du Chaillu used it in describing the work of previous explorers, and then Gray used it to describe du Chaillu, also calling him "an uneducated collector of animal skins for sale and an exhibitor of them in Broadway, New York." Thus, Du Chaillu's success with the public did little to help him: the true gentlemanly specialist sought recognition from his peers, who were qualified to judge the quality of his work, rather than from the public, who were not. ${ }^{33}$ The Athenaeum's use of "the New Traveller's Tales" as the heading for the section of letters about du Chaillu and the Explorations suggests what the editors thought about the issue.

Gray was not the only person to discover problems with du Chaillu's book. An anonymous writer to the Athenaeum pointed out that the implicit chronology of the voyages given in the book was impossible. Du Chaillu had given two different and

\footnotetext{
${ }^{30}$ John Edward Gray, "Zoological Notes on perusing M. Du Chaillu's Adventures in Equatorial Africa," Ann. Nat. Hist. 1861, 8:60-61; ibid., pp. 64-65.

${ }^{31}$ John Edward Gray, "The New Traveller's Tales," Athenaeum, 25 May 1861, p. 695; Bucher, "Canonization," p. 20 , n. 32.

${ }_{32}$ Gray, "Zoological Notes," Ann. Nat. Hist., 1861, 8:60; John Edward Gray, MS note in his personal copy of T. H. Huxley's Evidence as to Man's Place in Nature (London: Williams and Norgate, 1863). Collection of Sydney Ross, Troy, N.Y.

${ }^{33}$ Gray, "Zoological Notes," (cit. n. 30), p. 60; Susan Faye Cannon, Science in Culture: The Early Victorian Period (New York: Science History Publications, 1978), p. 150.
} 
mutually incompatible accounts of what he had been doing in the early months of $1858 .{ }^{34}$ With the entire chronology of the narrative thrown into question, all the individual parts of the narrative also became suspect.

Another of du Chaillu's detractors was an American trader named Walker, who had known du Chaillu in the Gabon. Walker contradicted many of du Chaillu's most sensational descriptions. Du Chaillu claimed that he had traveled alone and that he spoke the language of the natives. Walker asserted that du Chaillu had been accompanied by a Frenchman and had an interpreter. Du Chaillu wrote about being stranded on the coast for four months and being miraculously rescued by a trading ship. Walker countered that du Chaillu spent most of the time comfortably at an American mission and was only on the coast for two weeks. Du Chaillu had, in fact, arranged in advance to meet the ship. With these and other criticisms, Walker felt that he had "sufficiently shown that M. Du Chaillu has been guilty of many incorrect statements - in fact, his work contains almost as many errors and inconsistencies as there are paragraphs. It is, moreover, teeming with vanity; and, taking it as a whole, it is hard to say whether the author, in his attempt to impose upon and in fact humbug the scientific world, displays most mendacity or ignorance." ${ }^{35}$

The evidence provided by Walker and Gray seemed pretty damning, but there were other perspectives on the validity of du Chaillu's work. The reviewer in the Natural History Review of July 1861 argued that du Chaillu was neither particularly mendacious nor ignorant. Rather, the reviewer attributed the defects of the narrative to be the result of "imperfectly kept notes, assisted by the efforts of a rather vivid imagination and a not very perfect memory." He attributed the energy of the attacks against du Chaillu to jealousy: "We fear, owing to the somewhat over-zealous way in which he has been taken up and made a 'lion' of, that M. Du Chaillu has provoked such severe criticisms upon his performances; such, indeed, as, in our opinion, ought not to have been put forward, until the most positive and satisfactory evidence of the untruth of his statements had been obtained." ${ }^{36}$ This review makes explicit one of du Chaillu's key sins in the eyes of many British scientists: his public acclaim.

Science reviewers, naturally enamored of classification, identified du Chaillu's precise place in the constellation of scientific explorers. The reviewer for the Natural History Review argued that du Chaillu could not be a "scientific naturalist" because "he ... who 'feels the breath of a serpent against his face'; and who 'turns turtles' in fresh water lakes and then classifies them among the Mammalia in his list of newly described species, is no doubt a vigorous voyager and a lively narrator, but wants the knowledge and the sobriety of a man of science." Nor was du Chaillu even a "scientific traveller," for "he took no observations, either astronomical, barometrical, meteorological, or thermometrical." The reviewer found evidence of du Chaillu's honesty in these very mistakes and omissions - "that such errors as we have last described, are of the very kind that any one, intentionally deceiving, would most surely avoid." In spite of all du Chaillu's "not inconsiderable" shortcomings, then, the reviewer found du Chaillu "to be an energetic and active explorer." ${ }^{37}$ Such was the subtle hierarchy between the different categories of traveler.

\footnotetext{
${ }^{34}$ Gray, "The New Traveller's Tales," (cit. n. 31), p. 695.

${ }^{35}$ R. B. Walker, "M. Du Chaillu and his book," Athenaeum, 21 September 1861, no. 1769: 374; Bucher, "Canonization," pp. 20-21.

36 "The Fauna of Equatorial Africa," Nat. Hist. Rev., July 1861, 1:291.

${ }^{37}$ Ibid., pp. 288-289.
} 
Behind the polite facade of gentlemanly scientific debate, some gentlemen of science found other reasons to doubt du Chaillu. Charles Waterton, another pillar of the British scientific community, wrote "[Du Chaillu's] adventures with the gorilla are most formidable and false. . . . I suspect strongly that the traveller has been nothing but a trader on the western coast of Africa, possibly engaged in kidnapping negroes." ${ }^{38}$ This was a harsh judgment coming from a man whose own travel narrative had been widely doubted and ridiculed just a few decades earlier. In October 1861 George Ord, a member of the Academy of Natural Sciences of Philadelphia, told Waterton that members of the Academy thought that du Chaillu was of mixed race. "If it be a fact that he is a mongrel, or a mustee, as the mixed race are termed in the West Indies, then we may account for his wondrous narratives; for I have observed that it is a characteristic of the negro race, and their admixtures, to be affected to habits of romance." Even du Chaillu's friends suspected he was of mixed parentage. Du Chaillu's "diminutive stature, his negroid face, and his swarthy complexion," wrote one of his friends, "made him look somewhat akin to our simian relatives." ${ }^{39}$ It is not surprising that racism, which was such a strong part of the social fabric of the day, should also play an important role in the assessment of scientific claims. Members of disparaged races were also disparaged as scientific witnesses.

Du Chaillu's authority as a witness was undermined for several different reasons. The process by which his authority was undermined illustrates the original bases of that authority. Authority derives partly from the more obvious elements one would expect: logical consistency, originality, accuracy, and honesty in reporting observations. But it also derives from more subtle factors, such as respecting the intellectual territory of other scientists by not making claims in their areas of expertise, being of the right race, and not being too blatantly commercial and publicity-seeking. Du Chaillu had clearly faked parts of his book or allowed them to be faked, and so it was perfectly natural for the scientists to question the validity of his data. The criticisms of du Chaillu, however, went beyond the criticism warranted by his transgressions. Some of du Chaillu's claims for having discovered new species of animals would probably have ordinarily fallen within the bounds of normal scientific uncertainty. But because he was suspect as a witness, his ambiguous claims were dismissed out of hand.

\section{SAVING THE PHENOMENA: MURCHISON AND OWEN COME TO THE RESCUE}

Historians and sociologists of science have noted that there is normally a circular relationship between the observer and what is observed. Credible observations lend

${ }^{38}$ Charles Waterton, Essays on Natural History (1871), p. 582; cited in Barber, Heyday (cit. n. 2), p. 277.

${ }^{39}$ George Ord to Charles Waterton. 20 October 1861. Ord-Waterton correspondence, Library of the American Philosophical Society, Philadelphia. Du Chaillu's life had many similarities with that of the famous artist and naturalist John James Audubon. Both were born illegitimately of mothers of (at the time) unknown race in French colonies. Both men distorted their personal histories, with a tendency to dramatize their lives, and both functioned on the margins of the scientific establishment. Finally, both were subjects of the frequently vitriolic letters between George Ord and Charles Waterton. For a further discussion of Audubon, see Alice Ford, John James Audubon: A Biography (New York: Abbeville Press, 1988); Edward Clodd, Memories (New York: G. P. Putnam's Sons, 1916), p. 72 . 
authority to the observer; a credible observer lends authority to the observations. ${ }^{40}$ Du Chaillu's detractors questioned both the observer and the observations. Du Chaillu had powerful critics, but he also had powerful allies. Sir Roderick Impey Murchison, president of the Royal Geographical Society, and Richard Owen, the superintendent of the British Museum of Natural History, were his two most prominent defenders in England. Murchison and Owen, both of whom had much of their own credibility invested in du Chaillu, fought hard to reestablish du Chaillu's reputation for competence as an observer. Murchison tried to reassert du Chaillu's good character to support the evidence, whereas Owen used the evidence to try to deduce du Chaillu's good character.

The annual meeting of the Royal Geographical Society took place shortly after Gray had first publicly criticized the Explorations. Murchison took pains to defend du Chaillu in his presidential address to the Society. He was also defending the reputation of the Royal Geographical Society, where many of du Chaillu's discoveries had been displayed. Murchison had a personal stake in establishing the credibility of du Chaillu's narrative since some of du Chaillu's geographic observations confirmed one of his pet theories about the existence of a chain of mountains in Central Africa. ${ }^{41}$ Murchison affirmed du Chaillu's good character and his reliability as a witness. In describing du Chaillu's accounts of the gorilla, Murchison cited the authority of Owen to establish du Chaillu's credibility. Describing du Chaillu's accounts of the countryside, Murchison said that "strikingly attractive and wonderful as are his descriptions, they carry in themselves an impress of substantial truthfulness." Du Chaillu had "brought to us what most will admit to be unanswerable evidences of his fidelity of observation-evidences which the Council of this Society has considerately allowed him to exhibit in our own apartments in Whitehall place." Yet Murchison also distanced himself from du Chaillu, reminding his audience that du Chaillu "never claimed to be a man of science." 42

The editors of the Athenaeum quickly refuted Murchison's defence of du Chaillu. The editors acknowledged the importance of Murchison's endorsement of du Chaillu but noted that "Sir Roderick's favourable opinions will not reconcile the singular discrepancies of dates in M. du Chaillu's book. No amount of friendly oratory will make it possible for a man to have been in two distant places at the same time. ${ }^{43}$ Prominent scientists could use their social standing to reinforce weak or controversial evidence and observations, but social standing could not overcome logical inconsistencies.

Owen's turn to defend du Chaillu came at the September 1861 meeting of the British Association for the Advancement of Science (BAAS) in Manchester. Owen

\footnotetext{
${ }^{40}$ This is the "experimenter's regress," discussed in Harry M. Collins, Changing Order: Replication and Induction in Scientific Practice (London: Sage, 1985), Ch. 4. Steven Shapin has formulated an observational version of this concept in "The House of Experiment," (cit. n. 18), p. 376, n. 6.

${ }^{41}$ P. B. du Chaillu, Explorations et Aventures dans l'Afrique Équatoriale (Paris: Michel Lévy Frères, Libraires, Éditeurs, 1863), pp. vi-vii. Murchison was no stranger to controversy himself. His role in controversies in Victorian geology is documented in Martin J. Rudwick, The Great Devonian Controversy (cit. n. 18); James A. Secord, Controversy in Victorian Geology: The Cambrian-Silurian Dispute (Princeton: Princeton Univ. Press, 1986); and David Oldroyd, The Highlands Controversy: Constructing Geological Knowledge Through Fieldwork in Nineteenth-Century Britain (Chicago: University of Chicago Press, 1990).

${ }^{42}$ Sir Roderick Impey Murchison, “Anniversary Address,” Journal of the Royal Geographical Society, 1861,31:clxxxii-clxxxiii.

43 “Our Weekly Gossip," Athenaeum, 1 June 1861, no. 1753: 729.
} 
emphasized du Chaillu's natural history collections, which could be independently verified, and avoided discussion of du Chaillu's personal observations, which could not. Owen presented a paper discussing the specimens that du Chaillu had sold to the British Museum, but only peripherally mentioned any of du Chaillu's claims that could not be independently confirmed. In this way, many of du Chaillu's claims became Owen's while du Chaillu was eased out of the picture. Du Chaillu was present at that BAAS meeting and at the discussion of the paper, but appears to have had little to say. ${ }^{44}$

Owen lent credence to du Chaillu's narrative by focusing on du Chaillu's natural history collections. In one of the most dramatic passages of his book, du Chaillu described how he shot an attacking gorilla in the chest. Owen's paper confirmed this account, saying that the wounds suggested that the gorilla had indeed been shot in the chest. Gray subsequently published a letter in the Athenaeum saying the wounds were consistent with the gorilla having been shot in the back. Gray invited anyone who was interested to look at the wounds and decide for themselves (see Fig. 3). "I might cite many names of high authority in corroboration of what I have here advanced," he wrote, "but I am not disposed to appeal to any authority, however great, where the facts are open to all. On these, and these only, I shall rest my case." 45

The "facts" did not speak as clearly as Gray claimed. His own authority was important in establishing them as facts. Nor was he entirely successful in establishing them as such. Owen, who was defending himself as well as du Chaillu, rose to the challenge and argued that the facts did not speak for themselves. Owen cited the authority of a well-known hunter who argued that the same "facts" could be consistent with the gorilla having been shot from the front. But since the facts did not speak for themselves, and neither man had enough authority to defeat the other decisively, the debate over the bullet holes was simply dropped. The evidence remained suspect, neither proved nor disproved.

Du Chaillu's text was clearly tainted, but the task of sorting out the fraudulent from the merely exotic was beyond the capability of anyone in London. Du Chaillu had a geographic advantage over his detractors: he was the only person involved in the debate who had actually been to Africa. Although some evidence suggested that a few of du Chaillu's trips were faked, nobody in London could decisively prove them so. Since so few other travelers had been in the region, no other accounts existed by which du Chaillu's could be judged. Because of du Chaillu's geographic advantage, attempts in London either to support him or to discredit him had to focus on his character instead. T. H. Huxley, who had been watching the debate but not participating in it actively, remarked that "[S]o long as [du Chaillu's] narrative remains in its present state of unexplained and apparently inexplicable confusion, it has no claim to original authority respecting any subject whatsoever. It may be truth, but it is not evidence." ${ }^{66}$ Huxley recognized the potential value of du Chaillu's observations, arguing at the same time that du Chaillu's credibility was not sufficient for the observations to be categorized as evidence.

44 "Section D.-Zoology and Botany," Athenaeum, 14 September 1861, no. 1768: 347-349. Du Chaillu's presence was noted, but no comments of his were recorded.

45 "Prof. Gray to the President of Section D," Athenaeum, 21 September 1861, no. 1769: 373.

${ }^{46}$ Thomas Henry Huxley, Evidence as to Man's Place in Nature (London: Williams and Norgate, 1863), reprinted in Huxley's Man's Place in Nature and Other Anthropological Essays (New York: D. Appleton \& Co., 1898), pp. 71-72. 


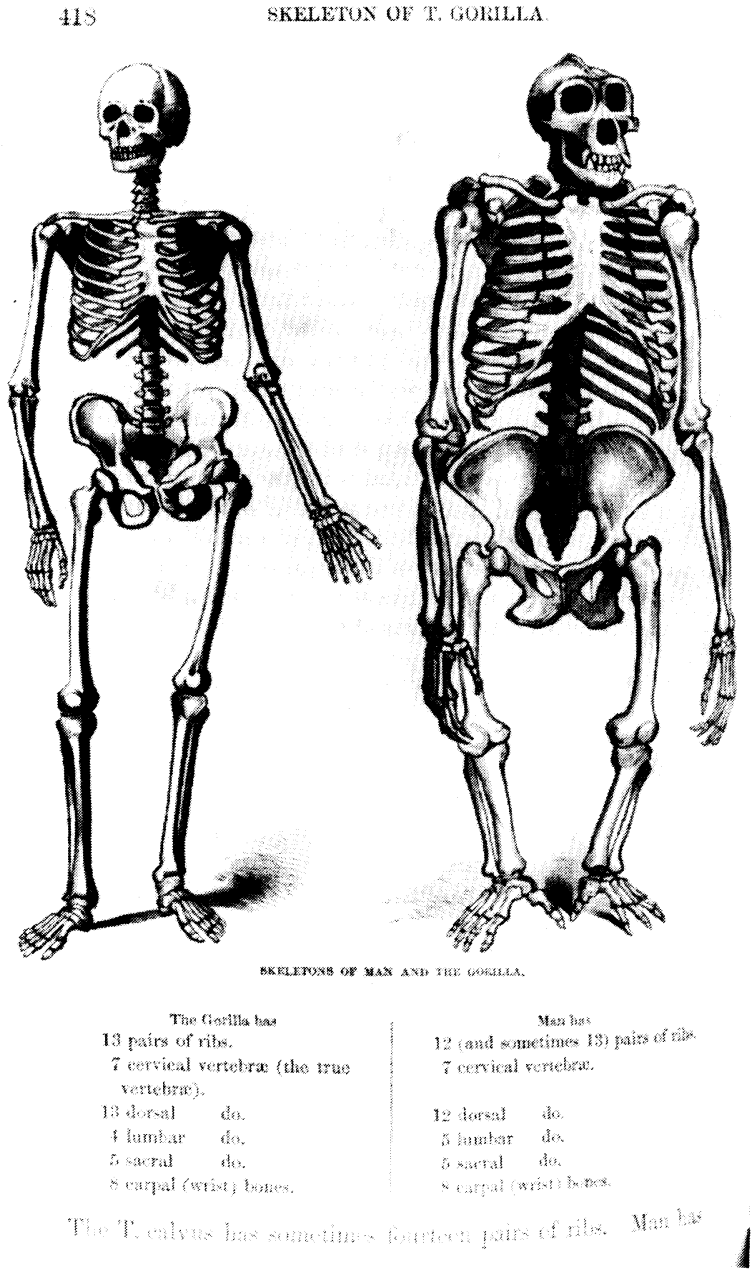

Figure 3. "Skeletons of Man and the Gorilla," from Explorations and Adventures in Equatorial Africa (New York: Harper and Brothers, 1861). John Edward Gray argued that this drawing was copied from a photograph of a gorilla skeleton. These photographs were sold as postcards at the British museum for a few pence. Even these simple drawings were also misrepresentations, since "the skeleton of the Gorilla is made stronger, broader, and more powerful, while that of the Man is proportionally diminished, so as to give anything but an accurate comparison." John Edward Gray, "Zoological Notes on Perusing M. Du Chaillu's Adventures in Equatorial Africa," Annals of Natural History, 1861, 7:465.

Du Chaillu's silence throughout the debates over the Explorations was a clear indication of his marginal status in the scientific community. Apart from one letter he wrote to the editor of the Athenaeum, his defense within the scientific community was carried out by others, gentlemen who were members of the scientific community. Even his supporters moved him to the periphery of the arguments, discussing du Chaillu only in the third person. The facts did not "speak for themselves" and du Chaillu did not speak for the facts. They always needed an interpreter of standing from within the community.

While the Athenaeum had been highly critical of du Chaillu, the editors saw a conclusion to the controversy only when Winwood Reade went to Africa in 1861 specifically to check out du Chaillu's claims. Reade was a twenty-three-year-old "traveller, novelist, and controversialist" who had studied at Oxford, although he did not take a degree. When he heard du Chaillu's stories, he raised money and went to the Gabon. For five months, Reade followed the path of du Chaillu's travels and interviewed many of the native porters and others with whom du Chaillu had 
worked. He confirmed many of du Chaillu's accounts about the geography and tribes of Western Africa, but rejected almost all of du Chaillu's accounts of the gorilla. ${ }^{47}$ When Reade returned to England in 1862, he presented his findings to the Royal Geographical Society and published articles in several magazines. In an observation that echoed the commentary on du Chaillu, Murchison said that "the Paper showed that Mr. Winwood Reade was an enterprising traveller, who had visited many parts of Africa, but not, as he modestly said, as a scientific man." 48

Reade's final assessment of du Chaillu and the Explorations is a curious mixture of criticism and sympathy. Reade concluded that the Explorations was a mix of truth and fiction, "prepared by a gentleman well known in the New York literary world" using du Chaillu's notes. Reade also found that du Chaillu's "labours as a naturalist have been very remarkable. And a fellow labourer, though a humble one, may be permitted to regret that, actuated by a foolish vanity or by ill-advice, he should have attempted to add artificial flowers to a wreath of laurels which he had fairly and hardly earned. ${ }^{49}$ Although Reade never names this mysterious figure in New York who helped du Chaillu write the book, his claim is plausible. Accounts of du Chaillu when he first arrived in the United States say that his English was not very good. Certainly it is very awkward in his early correspondence with Jeffries Wyman, during the time that du Chaillu was supposedly working on the book. The level of language used in the book is far superior to the language in his personal correspondence, suggesting that he had at least some strong editorial help. Quite possibly, the editorial process went from simply cleaning up du Chaillu's language to spicing up the facts.

Reade's letter was published in the Athenaeum in November of 1862, almost a year and a half after the controversy had broken. The editors of the Athenaeum, ignoring many of the debates that had taken place in the pages of their own journal, said that "[p]eople refused to believe that a book full of amusing contradictions and absurdities was true; and for this refusal they have now received from an English witness at the Gaboon a further and conclusive warrant." ${ }^{50}$ Although people from the Gabon gave convincing evidence of some fraud on du Chaillu's part within seven months of the beginning of the debate, it was not until a year later that Reade, an English witness and a gentlemanly emissary of the scientific community, provided an assessment credible enough that the debate could publicly be declared finished. Even though Reade was not "a scientific man," as Murchison pointed out, his Englishness and his rectitude made him a better witness than du Chaillu. Certainly Reade's own accounts of Africa were never given the same kind of critical scrutiny as du Chaillu's. Du Chaillu's observations had been superseded by those of a more credible witness.

Despite the judgments of the Athenaeum and John Edward Gray, much of du Chaillu's work did not fade from the public or scientific eye. Many of du Chaillu's observations fell legitimately within the bounds of scientific uncertainty. Reade's

47 “Reade, William Winwood," DNB, 47, pp. 361-362.

${ }^{48}$ W. Winwood Reade, "Travels in western Africa," Journal of the Royal Geographical Society, 1863, 7:106-107.

${ }^{49}$ Winwood Reade, "News From the Gorilla Country," Athenaeum, 22 November 1862, no. 1850: 662-223. Nobody has yet found the manuscript for the Explorations or correspondence relating to the publication of the work that gives any details about how it was put together.

50 "Our Weekly Gossip," Athenaeum, 22 November 1862, no. 1830: 665 (emphasis in original). 
explorations, for example, had also confirmed many of du Chaillu's observations. For the next sixty years most people who did field work on the gorilla took the Explorations as their starting point. Even if du Chaillu's claims were not proved, they did give subsequent explorers to the region an important list of observations to be confirmed, modified, or refuted. Du Chaillu had unintentionally helped to define the research agenda for subsequent natural historians, explorers, and anthropologists who visited the Gabon.

In 1863, du Chaillu returned to the same region of Africa to prove some of his more controversial points. He spent another several years there and got another book out of it. This second book, A Journey to Ashango-Land, was popular but not as controversial as the Explorations. The Explorations were also a motivating force behind Richard F. Burton's expedition to the area a few years later. "Travelling with M. Paul B. du Chaillu's "First Expedition" in my hand," Burton wrote, "I jealously looked into his every statement, and his numerous friends will be pleased to see how many of his assertions are confirmed by my experience." Burton devoted a chapter of the book to the gorilla. A French surveying party had by then largely confirmed many of du Chaillu's geographical discoveries. Nonetheless, many of the facts concerning the habits of the gorilla were still disputed as late as 1876..$^{51}$

Later assessments of du Chaillu varied. An 1881 account of du Chaillu's first book notes that some of the facts that du Chaillu had discovered on his first trip had "excited unreasonable and unreasoning hostility in England." ${ }_{22}$ This assessment was not universally shared. In their pioneering study on primate life, the famous primatologists Robert and Ada Yerkes found du Chaillu to be "grossly careless in exposition, and perhaps also handling of the gorilla exhibits. At any rate his publications were so far repudiated by the scientific world that even today [1928] they are considered first rate examples of 'nature faking'... . However charitable his inclination, one must admit that his showing is bad." 53 The explorer Carl Akeley argued that du Chaillu had grossly misrepresented the behavior of the gorilla. "If you read the tale as Du Chaillu wrote it, it gives an impression that the gorilla is a terrible animal. If you read merely what the gorilla did, you will see that he did nothing that a domestic dog might not have done under the same circumstances. . . All I want to point out is that the gorilla should be judged by what he does, not by how the people who hunt him feel." ${ }^{54}$ Whatever the final assessment, it is significant that for more than fifty years after the Explorations were written, people who worked with primates often felt obliged to address du Chaillu and his discoveries. This is a telling indication of the extent of his impact.

Paul du Chaillu was far from ruined by this scientific controversy. While this study has focused on the reception of du Chaillu and the Explorations by the scientific

\footnotetext{
${ }^{51}$ Richard F. Burton, Two Trips to Gorilla-Land and the Cataracts of the Congo, 2 vols. (London: Sampson Low, Marston, Low, and Searle, 1876; reprint edition, New York: Johnson Reprint Corporation, 1967), p. vii; Paul du Chaillu, A Journey to Ashango-land: And Further Penetration into Equatorial Africa (London: J. Murray, 1867).

${ }^{52}$ Charles H. Jones, Livingstone's and Stanley's Travels in Africa, also; the Adventures of Mungo Parke, Clapperton, DuChaillu, and other Famous Explorers in the Land of the Palm and the Gorilla (New York: Hurst \& Co., 1881), p. 220.

${ }^{53}$ Robert M. Yerkes and Ada W. Yerkes, The Great Apes: A Study of Anthropoid Life (New Haven: Yale University Press, 1929; reprint edition, New York: Johnson Reprint Corporation, 1970), p. 34.

${ }^{54}$ Carl E. Akeley, In Brightest Africa (Garden City, N.Y.: Garden City Publishing, 1923), pp. 237-239.
} 
community, scientists were never a major part of his audience. Months after most scientists had washed their hands of him, he could still pack lecture halls and earn several hundred pounds in a single evening lecturing to the public. His second voyage to Africa was financed by the proceeds from the animals he sold to the British Museum. He also wrote a highly successful series of children's stories loosely based on his two voyages to Africa. Du Chaillu supported himself from the proceeds of these books and by giving public lectures about his experiences in Africa. With the proceeds he spent several years in Scandinavia, resulting in the two-volume ethnography entitled Land of the Midnight Sun, which earned him even more money and got him invited to more lectures. He was working on a similar ethnographic study of Russia when he died in $1903 .{ }^{55}$

\section{CONCLUSION}

The field sciences in Victorian England and the United States depended heavily on trust. Out of necessity, metropolitan scientists accepted reports and collections from people who were on the social margins of the scientific world but who had privileged access to the field. Their elaborate strategies for incorporating collectors and their reports and collections into the scientific sphere generally worked well. Both the explorers and the societies benefited from the exchange. Where the field reports fit with what was previously known, they were accepted without a murmur of dissent and indeed sometimes with celebration. The controversy over the Explorations and Adventures in Equatorial Africa made the fundamental weakness of this system clear to all. It illustrated a crucial difference between the laboratory sciences and the field sciences. In the laboratory, all experiments are at least in principle independent of time and space. Doubts can be resolved by repeating the experiment. In contrast, the field sciences depend heavily both on time and on space. Replicability, particularly in the nineteenth-century field sciences, was difficult, if not impossible. Accordingly, the field scientists depended much more heavily on authority than did the laboratory sciences.

Authority could be vested in objects and texts as well as people. The substantial natural history collections offered proof of du Chaillu's accomplishments in Africa. The authority of other natural history objects was, however, subject to different interpretations. The bullet holes in the gorilla skin were not sufficient to prove du Chaillu's account one way or another. The Explorations was criticized for its "fantastic" accounts, but equatorial Africa was also a place where Europeans expected to encounter the fantastic, so little that du Chaillu said was inherently implausible. The chronological contradictions and basic scientific mistakes in the narrative effectively undermined its independent authority. Given that neither the authority of the evidence nor that of the text was sufficient to establish truth, attention turned to du Chaillu himself. Just as they dissected the mammals and insects in their collections,

\footnotetext{
${ }_{55}^{5}$ Paul du Chaillu, The Land of the Midnight Sun: Summer and Winter Journeys Through Sweden, Norway, Lapland, and Northern Finland (New York: Harper \& Brothers, 1882). Some of the more popular of du Chaillu's children's books include Lost in the Jungle: narrated for young people (New York: Harper \& Brothers, 1870); Stories of the Gorilla Country: narrated for young people (New York: Harper \& Brothers, 1881); Wild Life under the Equator (London: Sampson Low, Son \& Marson, 1869); The Country of the Dwarfs (New York: Harper \& Bros., 1899); and My Apingi Kingdom: with life in the great Sahara, and sketches of the chase of the ostrich, hyena, \&c. (New York: Harper \& Brothers, 1871).
} 
scientists in Victorian London minutely dissected Du Chaillu's credibility into its component parts - personal background, education, race, social class — and found it wanting. Nor were Owen and Murchison's authority sufficient to reestablish the credibility either of du Chaillu or of his narrative.

Since appeals to authority did not resolve the question, attention shifted back to the field. Although it was impossible to replicate du Chaillu's observations precisely, it was at least possible to follow in his footsteps. Even so, no crucial experiment could decisively prove du Chaillu wrong. If subsequent travellers did not see the things that du Chaillu claimed to have seen, such observations did not, in and of themselves, refute du Chaillu's claims. Observing docile gorillas did not prove that gorillas never attacked. Instead of being decisively refuted, the authority of du Chaillu's observations was gradually eroded over the next fifty years. During these years, scientists began to resolve the problem of field observations either by going into the field themselves or by sending trained observers to the field. Instead of moving parts of the field back to the metropolis, scientists increasingly moved parts of the metropolis out to the field. By doing so, they got around the weakest link in the field sciences, their traditional dependence on untrained collectors. Replicability was still impossible, but at least scientists could bring their knowledge and authority to field observations with no mediations. Anybody could discover truth, but as far as scientists were concerned, only scientifically trained people could turn that truth into evidence. 